\title{
Four Ways to Expand the Foundation for CPED's Social Justice Framework
}

\author{
Four Arrows, EdD \\ Fielding Graduate University \\ djacobs@fielding.edu
}

\begin{abstract}
This article offers recommendations for deepening and expanding the important ideas about social justice that are presented in the current CPED social justice framework for the EdD. One suggestion is to better articulate the fact that social justice is ultimately inseparable from ecological justice, sustainability and diversity. I also argue that it is best if the proposed framework's reference to the knowledge economy include awareness of the possibility that it can be as destructive as a material-based one. Although the framework report does mention community as a target for social/ecological justice, sustainability and diversity (SEJSD), it tends to focus primarily on its application in education settings. This paper emphasizes a greater expansion of SEJSD into the world of social/ecological justice education. Finally, I suggest a foundation for CPED's framework that includes "project-based learning" whereby work on the EdD program's final project, whether a capstone or dissertation, start "from day one" and be the focal point for all coursework. Such a process, common in most International doctoral programs, will assure SEJSD and mastery of a chosen topic area are at the highest level of interdisciplinary and will help encourage the kind of praxis in the real world the EdD should require, especially in the Trumpian era we entered on January 20, 2017.
\end{abstract}

\section{INTRODUCTION}

Before reading an earlier version of "Centering Social Justice in EdD Program", the opening piece of this special issue authored by my friend, colleague and social justice champion, Brad J. Porfilio and his colleague Kathryn Strom, I had been critical of CPED's work for not sufficiently addressing "social justice." In a chapter I wrote for book, The Education Doctorate, I noted that educational hegemony has stifled the EdD's optimal potential for implementation (Stead, 2015). I use Brookfield's definition for hegemony as being "the process by which we learn to embrace enthusiastically a system of beliefs and practices that end up harming us and working to support the interests of others who have power over us" (p. 94). As someone who has written extensively about the hegemony in schools (Four Arrows, 2013), I saw CPED's six principles for designing an educational doctorate program as needing to be significantly stronger as relates to its important social/ecological justice emphasis. "Not even the Carnegie Project on the Educational Doctorate (CPED), a prestigious research project started in 2007, has produced significant literature about educational hegemony's influence on the problems it has supposedly been addressing" ( $p$. 199). As an Indigenous scholar and critical theorist I write this piece with counter-hegemonic eyes and offer an expanded perspective for enhancing the language, intentions, and scope of the framework. Specifically, I recommend four enhancements for operationalizing social/ecological justice, sustainability and diversity social/ecological justice, sustainability and diversity (SEJSD) education for the EdD.
These include:

- Adding ecological considerations such as ecological justice, sustainability and diversity to the social justice language;

- Representing a more holistic understanding of the knowledge economy;

- $\quad$ Significantly expanding the focus of SEJSD beyond the university setting;

- Including a recommendation for the EdD earlier and more intense work on the dissertation or final research project as is generally done in most international doctoral programs.

\section{ADDING ECOLOGICAL CONSIDERATIONS}

This first suggestion is about consistently using language that weaves ecological justice and sustainability into any social/ecological justice documents or conversation. The current CPED framework does not do this yet. Referring to the slippery slope concerns about defining social justice, it does talk about the importance of "explicitly
New articles in this journal are licensed under a Creative Commons Attribution 4.0 United States License.

This journal is published by the University Library System of the University of Pittsburgh as part of its D-Scribe Digital Publishing Program and is cosponsored by the University of Pittsburgh Press.

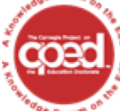

This journal is supported by the Carnegie Project on the Education Doctorate: A Knowledge Forum on the EdD (CPED) cpedinitiative.org 
defining the way the term is conceived in particular problems". ${ }^{1}$ This reference might open the door for a professor or student to make an ecological connection, however I suggest more explicit instructions for this are important. It took me years to get my own social-justice oriented university to include "ecological" when referring to social justice, and too many dedicated social justice educators in our anthropocentric world continue miss the vital connection. Whenever we refer to social justice it is important to include ecological justice as well. If the new EdD guidelines change, doing so might positively impact the current ecological crises and its causal and consequential injustices. Language is important. Leaders in higher education and in social justice movements who understand the inseparability of social, ecological, and economic systems (Rixecker \& Tipene-Matua, $2003 / 2012$ ) can better serve the social justice issues targeted by the CPED framework.

Bringing ecological considerations into the picture when referring to social justice allows educators to discuss the problems of anthropocentrism and its influence on justice education. I suggest that our human-centered orientation toward having superiority over animals and a fear of the natural world begins the journey of humanversus-human injustice. Once we are able to feel superior to any life form, this sets the stage for looking down on people who are different (Four Arrows et al., 2010). Unfortunately, the idea of human superiority and hierarchy over animals, rivers, trees, etc. continues to guide human economic and political choices, too many of which lead to injustice, inequality, and disrespect for diversity as well as leading us closer and closer to the reality of a sixth mass extinction (Kolbert, 2014). One of the first things that non-Indian supporters who came to the Dakota Access Pipeline protest at Standing Rock learned was that the mighty Missouri River was not just "water" but mni wiconi-the essence of life-giving as is mother's milk from the breast. It is life itself and deserves respect accordingly.

In 1987, the United Nations referred to anthropocentrism versus biocentrism in describing links between environment, social justice, and peace (World Commission on Environment and Development, 1987) but such ideas seldom make their way into teacher training programs. Of course, many scholars have recognized the importance of connecting social to environmental justice in general (Schmitz et al., 2012), but still do so in a human-centered way. For example, Besthorn (2006) writes, "Social work can no longer afford to miss the message that as the environment goes so goes human development" (p.2). As long as the connection is seen as solely for the benefit of humans we will continue to destroy all of life on the planet. Until we do as we did for most of human history and what traditional Indigenous Peoples are still doing whereby we consider

\footnotetext{
1 Note that I'll use quotation marks when citing from the "Foundational Framework" article by Porfilo et al but without repetitive referencing. I understand the publishers of this journal must put my citations into APA and only respectfully and with understanding state here it is not with my blessing. My own university also continues to require the use of APA in spite of my please to take a stand in light of the organization's unpunished collusion and cover-up regarding the CIA's illegal torture policies and a number of other horrific contributions to social injustice I write about in my article at Truthout in 2014 entitled "Are Eugenics, Torture and Social Control Hidden Legacies of the American Psychological Association?").
}

rivers, trees, and frogs as having intrinsic value and as co-conscious entities, even as teachers, the foundation of superiority will remain a root cause for such destructive behavior.

For many years I have conducted an experiment to help people realize that there is a living, intelligent, spiritual energy in even plants. I simply ask students or workshop participants to go outside and touch one quickly then return to the classroom. Next, I ask them to go outside again, but this time I tell them to ask it permission before touching it and to wait for a response before doing so. Over the years the feelings participants describe when they return are remarkable in how they describe a reciprocal communication, with many stories bringing forth tears. Imagine if we lived life this way continually and thought of "natural resources" as our sacred relatives. How might this change the way we treat water, trees, and other-than-human (or greater-than-human) life?

Rethinking the dominant human-centered view may be a prerequisite for addressing the pitfalls of capitalism's contribution to ecological crises also. Economic externalities that create social and ecological injustices and loss of biodiversity would have to be reconsidered if other-than-humans received respect for having intrinsic value rather than only utilitarian value. In the libertarian view, which on this point is supported more or less by most people, everything on earth has only instrumental value for humans. Loyola economics professor and author, Walter Block (2011) writes, "I regard humans as of intrinsic value and animals, plants, minerals, etc., as only of instrumental benefit insofar as they promote human welfare" (p.102). ${ }^{2}$

In short, man has rights because they are natural rights. They are grounded in the nature of man: the individual man's capacity for conscious choice, the necessity for him to use his mind and energy to adopt goals and values, to find out about the world, to pursue his ends in order to survive and prosper, his capacity and need to communicate and interact with other human beings and to participate in the division of labor (p.44).

This manner of thinking lays the foundation for social and ecological injustices, from structural inequality to genocide. Once we assume superiority over anything in Nature, it can lead to a hierarchy over other people for whom we erroneously perceive as superiority.

There are many connections between social justice and ecological issues beyond those that relate to human-centeredness that are not typically or sufficiently included in curriculum for the EdD. For one, students ought to have courageous conversations about the role of organized religions in promoting destruction of Earth's life systems and injustices of all sorts (Four Arrow, 2014). For another, students should explore the important connections between poverty and environment. Poverty has a devastating effect on climate change, deforestation and water pollution because people in poverty over-rely on wood and use unsustainable agricultural methods. Wealthy people force people into poverty owing to exploitation of

\footnotetext{
${ }^{2}$ Because I have disagreed with most of what Dr. Block has written over the years, I invited him to co-author a book with me in which we had to "argue cooperatively" rather than "debate." This quote comes from our book and although I still disagree with it, we did find common ground and share a friendship, strange bedfellows that we are.
} 
environment that destroys local livelihoods. People on the low end of the hierarchy suffer most from climate change problems. Without deep awareness of ecological interconnectedness and whether as a matter of survival or not, rich and poor alike aspire toward lifestyles emphasizing consumption. The result will come to a head as depletion of water, soil health and food itself continues to create conflict. Because violations of SEJSD stem from unawareness about these links (Blowers, 2003), and because education is the tool for awareness, the EdD has a responsibility to include SEJSD in its curricula.

\section{IMPLEMENTING A MORE HOLISTIC UNDERSTANDING OF THE KNOWLEDGE ECONOMY}

As ecological issues are inseparable from social justice, so too are economic realities. Unlike ecological issues, economic ones are not generally ignored in day-to-day decisions. Strom and Porfilio call attention to economic contributors to social injustice when it rightly identifies "the neoliberal" "corporate" reform movement that seeks to privatize, standardize, and deregulate school systems" and "an economically-motivated push for "twenty-first century skills" to meet job demands of the knowledge economy." These authors also recognize education's responsibility: "Against a backdrop of global economic crises, these trends are expanding the historically entrenched inequalities that have been perpetuated by our educational institutions." Yet without more specific direction supplied in guidelines for higher education curricula about the growing knowledge economy, a blanket acceptance of its dependence on destructive potentialities is likely to continue.

The EdD curriculum must offer alternative perspectives about the knowledge economy. If the CPED consortium embraces it without serious critical reflection, it misses a vital opportunity for dialogue about all factors that are preventing sustainability and justice. Strom and Porfilio are right in pointing out the potential for the concern about unequal access to skill acquisition and employment access, but a larger problem exists as relates to sustainability and wealth distribution. Educators at the highest level must understand how the knowledge economy itself, not just the privatization movement, is closely linked to neoliberal globalization and rapid environmental destruction (Brinkley, 2006). High tech design, business services, management, financial services, health, and education may seem benign and even preferable to materialbased economies, but it can go either way depending on how we educate ourselves. Is computer technology really more eco-friendly for reading and learning than bound books or newspapers?

People in EdD programs are in a position to study the ecological impact of our constant expansion of technology. Student projects can compare situations in various locations or between first and third world environments. They can look at consequences in their own schools and in the communities in which they reside of how service and knowledge based economic phenomenon might be understood in ways to mitigate ecological problems. However, without the awareness that the knowledge economy can indeed be more destructive than a material-based economy, we are unlikely to make the wisest decision with respect to the future of the planet.

For example, in higher education, more and more schools are using telecommunications as part of administrative systems and teaching without considering possible social/ecological justice or sustainability impacts. Educators at the doctoral level should be aware of whether or not educational technology itself might be responsible for ecological imbalance. In an article titled Helping Teachers Respond Meaningfully to Technology, Nichols (1993) writes that educational technology is deleterious to education and the environment and that we are morally responsible for how others are affected by it. Chet Bowers $(1988,1993)$ also writes about the unthinking culture of schools and about how their educational technologies contribute to ecological injustice and threats to sustainability (Bowers, 1993). Kenway et al. (2006) writes that we may not be able to say for certain that techno-scientific innovation in the knowledge economy will help or hurt but that we must at least seriously discuss and measure possibilities

Who will put such options on the table for future economists to consider? Educators are responsible for creating K-16 curricula that prepare people to reason, intuit, and think creatively about the interconnected and potential consequences of decisions made in the knowledge economy. Peters (2011) argues for such education in an article about "greening the knowledge economy."

The most sustainable and 'productive' interface in advanced postindustrial societies in the twenty-first will be that between the knowledge and the 'green economy.' It charts three forms of the knowledge economy - the 'creative', 'learning' 'open science' economy - each of which profiles education as a central activity and 'learning processes' as the source of intellectual energy driving the new educational environment and shaping emergent knowledge ecologies. It discusses the significance of network analysis as a broad methodology that provides the basis in terms of policy for yoking large systems together - ecosophy, ecology and economics and social, ecological, and economic sustainability. It also proposes a postmodern critique of neoliberal economics before examining conceptions of the green economy and its sustainability. (p.14).

Peters encourages educators to look more broadly, "at the need for a broad shift from anthropocentric conceptions of economy to one based on a systems framework, and in this light, considers the relations among eco-politics, environmental education and prospects for green capitalism" (p.22). As part of its anti-neoliberal orientation, Strom and Porfilio's piece can help stimulate EdD students and graduates to take the lead in embracing and advocating for these alternative perspectives.

\section{EXPANDING THE FOCUS OF SOCIAL I ECOLOGICAL JUSTICE BEYOND THE UNIVERSITY SETTING}

A third concept in Strom and Porfilio's piece has to do with, what I see as, the ultimate goal of education and the CPED project itself- making the world more socially and ecologically just in the world at large, not just within the educational systems alone. As it stands, Strom and Porfilio are not sufficiently clear on whether SEJSD is only about education issues per se or about preparing educators to engage the serious threats to democracy, equal treatment, economic fairness and ecological sustainability outside the schools in communities and workplaces. As it is, the authors' ideas might be interpreted as looking only at problems of professional practice in educational processes, such as fair treatment of students, diverse student populations, etc. If so, this focus on organizational justice alone, teaching mostly about procedural, interpersonal, and distributed fairness within schooling, 
may prevent the new EdD from curbing hegemonic forces that are destroying healthy life systems everywhere. The following passage from their piece prompts the question as to whether or not CPED's reference to "problems of practice" relates to the practice of education or also to the practices of corporations, governments, and other groups.

Accordingly, the principles of the Carnegie Project on the Educational Doctorate (2009) promote the development and continuous improvement of professional doctorate programs that are "framed around questions of equity, ethics, and social justice to bring about solutions to complex problems of practice." This principle is grounded in work such as that of Shields (2014) which states:

One cannot argue for the excellence of a school, regardless of test scores, if there are some groups of children who are misplaced in low-level special education classes; if certain groups of students are over represented in suspensions, dismissals, or dropouts; if parental wealth determines class or program placement; or if the curriculum is narrow and sterile and focused on test attainment rather than learning. These injustices in actuality prevent a school from being both socially just and academically excellent. The two go hand in hand. (p.)

Such concerns remain important but the EdD emphasis on social/ecological justice must move beyond this internal focus that conceptualizes only as it relates to program development, coursework, student advising, research methods and to dissertations. I know this sometimes takes courage. I was on the front lines when the National Council for Accreditation of Teacher Education (NCATE) removed "social justice" from the list of desired dispositions for teachers. Clarity about purpose is especially important. Strom and Porfilio do refer to "explicitly defining the way the term is conceived in a particular program and articulating the bodies of theoretical literature from which that definition is constructed and actively connecting that contextual conceptualization of social justice to the ways it informs action in the doctoral program, but this is too ambiguous and allows for status-quo thinking. However, without realizing the role education must play in human survival, this focus will fall short. Status quo in education is a powerful force. My own university almost expanded its focus with a stronger pro justice and sustainability vision but status quo forces stifled it. When I wrote about the project I was excited that we might become "the first survival university" but knew there was a high chance that faculty and administrators would see it as too bold. (This is the reason I added the question mark in my piece about it on Truthout entitled, The First Survival University? (Four Arrows, 2015). However, we have a chance with a new EdD degree to emphasize curricula that connects classroom counter-hegemony to real-world education before it is too late.

\section{AN EARLIER, MORE INTENSE FOCUS ON THE FINAL RESEARCH PRODUCT}

One way to help achieve the goals for a more intentional focus on social/ecological justice and sustainability within the new EdD is to have students to come into the program with a relevant research agenda in mind that they will start studying immediately. Instead of merely absorbing what faculty feel is important to teach during the first two years, students should use coursework to work toward mastery of their focus from day one. In "The Authentic EdD Program: Project-based and Counter-hegemonic" (Four Arrows, 2015), I write that EdD graduates often perpetuate the beliefs of their instructors and administrators who are still clinging to competitive work; authoritarian expertise; hierarchy; letter grading; rigidly structured dissertations that stifle critical thinking and creativity in spite of the mandate for making an original contribution to literature and who in one way or the other stifle speaking truth to power in a politicallyoriented curriculum. Doing project-based learning that relates to improving educational practice in ways that prepare educators to help students become change agents can make the EdD a more vital tool in behalf of human survival. It helps assure that EdD students deeply engage and study interdisciplinary aspects of a research project and praxis early on or even before admittance to the program. The content of syllabus-driven coursework can be negotiated for each student so as to provide a unique lens through which to better understand their research focus, a focus that attends to the most serious educational concerns of our time. How the research is represented can be a capstone project description and summary; a participatory action research log; a five-chapter dissertation or a creative alternative dissertation, but instead waiting until coursework is done to start learning to master the student's main interest, work on it begins immediately or even before entry as is done in many international doctoral programs.

When students decide upon their research focus, whether relating to curriculum, instruction or policy, faculty should encourage them strongly to consider SEJSD aspects of their interest and plans for the final project. Every life system is at a tipping point and injustice prevails in so many ways that it is difficult for me to imagine someone wanting to do a dissertation research project that would not make a connection to SEJSD, whether global issues in the world or specific to problems of practice in education per se. The dispositions, knowledge, and skills needed should not be ancillary add-ons to the EdD curriculum, but part of the broader goals of education to create full human beings who know how to learn and contribute in ways that help to express their full, positive mental, physical, social and spiritual lives. The goal of the EdD is not "to get a job as a professor" or "to get a salary increase." What makes the EdD work that is currently being conducted by the CPED exciting is that it has a chance of changing what many critical theorists have claimed about the existing hegemonic functions of education. EdD degree work must stimulate critical and intuitive consciousness, virtues for acting on what is discovered to be for the greatest good, and skills for influencing transformation when appropriate. Greg Cajete (1994) refers to such goals as "seeking, finding, being with, and celebrating spiritual ecology" as relating to "becoming complete, of good heart, of good thought, with harmony" (p. 46).

It is true that such education may be most important and most effective during a child's early years. However the role of "higher education" is key to how future educators ultimately prepare children to be citizens. Thus the EdD with the goals and perspectives I have offered can truly become one of the most important doctoral degrees offered in higher education. We can no longer afford to ignore the challenges facing our world nor the hegemony that causes us to be in denial of them. Perhaps it has always had this potential and this is why it has faced such systemic challenges from the established academy. Whatever the barriers to what some may consider an idealist, radical vision for the EdD such as I have proposed must be overcome if we are to have a chance to mitigate education's role in the global challenges that are facing us today. 


\section{REFERENCES}

Besthorn, F. H. (2006). "Instructional techniques for social work education: Insights from deep ecology in its Norwegian cultural context." Universitas: On-line journal of research, scholarship and creative activity, 2(1), 1-18.

Block, W. (2011) "Ecological justice" in Four Arrows and Block W., Differing worldviews in higher education: Two scholars argue cooperatively about justice education. Rotterdam: Sense Publishers

Blowers, A. (2003). Inequality and community: The missing dimensions of sustainable development. In: S. Buckingham, K. Theobald (Eds.), Local environmental sustainability, pp. 235-250. Boston, Woodhead Publishing Limited

Bowers, C.A. (1988). The cultural dimensions of educational computing. New York: Teachers College Press.

-- (1993). Education, cultural myths, and the ecological crisis: toward deep changes. Albany, NY. SUNY Press.

Brinkley, I. "Defining the knowledge economy. The work foundation. London: Carlton House. Web. Accessed 4/23/2016 at http://www.theworkfoundation.com/assets/docs/publications/65_defining $\% 20$ knowledge \%20economy.pdf

Brookfield, S. D. (2005). The power of critical theory: Liberating adult learning and teaching. San Francisco, CA: Jossey-Bass

Cajete, G. (1994) Look to the mountain: An ecology of Indigenous education. Durango, CO: Kivaki Press

Four Arrows (2008) The authentic dissertation: Alternative ways of knowing, research and representation. London: Routledge

Four Arrows (March 15, 2010): "Anthropocentrism's antidote: Reclaiming our orientation to the non-human teacher." In Critical Education, Edited by E. Wayne Ross et al. University of British Columbia.
Four Arrows (September 15, 2014). "False doctrine" and the stifling of Indigenous political will in Critical education. Vol.5, No.13., Vancouver, University of British Columbia

Four Arrows (2015). "Hegemonic barriers to the American EdD" in Stead, V. (Vol.Ed.) The education doctorate (Ed.D.): Issues of access, diversity, social justice and community leadership. In V. Stead (Series Ed) Higher education theory, policy, and praxis, Vol.5. New York: Peter Lang

Kenway, J., Bullen, E., Fahey, J., \& Robb, S. (2006). Haunting the knowledge economy. New York: Routledge

Kolbert, Elizabeth. (2014). The sixth extinction: an unnatural history. New York :Henry Holt and Company

Nichols, R. G. (1993). Critical theory, educational technology, and ethics: helping teachers respond meaningfully to technology. In M. Simonson \& K.O. Abu, eds. The 1993 Proceedings of Selected Research Paper Presentations. Washington, DC: Association for Educational Communications and Technology.

Peters, M.A. (2011) "Greening the knowledge economy: Ecosophy, ecology and economy" in Economics, Management and Financial Markets. Vol. 8 (2), pp. 11-38

Rixecker, S and Tipene-Matua, B. (2012) in Agyeman, Julian, Bullard, Robert D., \& Evans, Bob (Eds) Just sustainabilities: Development in an unequal world. London: Earthscan: 2012. (Originally published in 2003 by MIT Press as "Maori Kaupapa and the Inseparability of Social and Environmental Justice: An Analysis of Bioprospecting and a People's Resistance to Bio cultural Assimilation")

Schmitz, C. L., Matyók, T. Sloan, L., \& James, C. D. (2012). The Relationship Between Social Work and Environmental Sustainability: Implications for Interdisciplinary Practice. International Journal of Social Welfare, 21(3) 278-286.

World Commission on Environment and Development (1987). Our common future. New York, Oxford University Press. 